\title{
Chapter 12 \\ Echoes and Influences of Realistic Mathematics Education in Portugal
}

\author{
João Pedro da Ponte and Joana Brocardo
}

\begin{abstract}
This chapter traces the connections between Realistic Mathematics Education (RME) and Portuguese developments in mathematics education in terms of research studies and curriculum development. The basis for this work is a literature review of papers and other documents, with special attention to the period 20052015, and research studies organised by mathematical topic. Although there is no research group in Portugal that is perfectly aligned with RME principles and curriculum materials, noticeable influences may be seen in the frequent references made in some research groups to key RME ideas, notably the importance of students working from tasks in meaningful contexts, the role of representations and models to support students' thinking, and the levels of students' mathematical activity. This is most noticeable in conceptual frameworks for developmental research studies in the area of number and in the use of realistic contexts in task design, and it is also apparent in the official 2007 Portuguese curriculum document.
\end{abstract}

Keywords Tasks $\cdot$ Representations $\cdot$ Numbers $\cdot$ Algebra $\cdot$ Geometry

\subsection{Introduction}

Realistic Mathematics Education (RME) has a clear influence in Portugal, both in research and in curriculum development. Portuguese mathematics educators began to know about RME ideas from reading Freudenthal (1973) and from their participation in two international meetings, that of PME (International Group for the Psychology of Mathematics Education) and of CIEAEM (International Commission for the Study and Improvement of Mathematics Teaching), which both took place in

\author{
J. P. da Ponte $(\bowtie)$ \\ Instituto de Educação, Universidade de Lisboa, Lisboa, Portugal \\ e-mail: jpponte@ie.ulisboa.pt \\ J. Brocardo \\ Escola Superior de Educação, Instituto Politécnico de Setúbal, Setúbal, Portugal \\ e-mail: joana.brocardo@ese.ips.pt \\ (C) The Author(s) 2020 \\ M. van den Heuvel-Panhuizen (ed.), International Reflections \\ on the Netherlands Didactics of Mathematics, ICME-13 Monographs, \\ https://doi.org/10.1007/978-3-030-20223-1_12
}


the Netherlands in 1985. Since then, contacts have been frequent, in other international meetings, in study visits made by Portuguese researchers to the Freudenthal Institute (FI) in Utrecht, and also through the visits made by researchers of the FI to Portugal to attend mathematics education conferences, ${ }^{1}$ to participate in activities of research and evaluation projects, and to deliver seminars to doctoral students. ${ }^{2}$

Research in mathematics education in Portugal began its development from the 1980s, with several doctoral degrees obtained abroad (in the United States and the United Kingdom), but only in the 2000s did it become more intensive, with doctoral degrees offered at several Portuguese universities (mainly in Lisbon, Aveiro, and Braga). It was around these doctoral programmes that the most important research groups developed, with the association of several schools for higher education (such as those in Lisbon, Setúbal, and Viana do Castelo).

In this chapter, we give an account of the main influences of RME in Portugal, with special attention for the last 10 years (2005-2015). The chapter is constructed from a revision of doctoral theses, edited books, articles published in mathematics education national and international scientific journals (Quadrante, BOLEMA, Relime, Uni-Pluri/Versidad), articles published in the teacher journal Educação $e$ Matemática of APM (Associação de Professores de Matemática ${ }^{3}$ ) and communications in proceedings of the national mathematics education research meetings SIEM (Seminário de Investigação em Educação Matemática) and EIEM (Encontro de Investigação em Educação Matemática). The chapter contains two main sections, one concerning research studies (subdivided in mathematical topics) and another concerning curriculum development. In each section, the studies and documents are highlighted in which the influence of RME ideas appears to be stronger, seeking to identify the main contributions to theory and practice of mathematics education as well as the aspects in which this influence may be traced. The chapter concludes with a summary of RME influence in our country.

\subsection{Influences on Research Studies}

\subsubsection{Whole Numbers and Operations}

The notion of number sense inspired several researchers of the Developing Number Sense (DNS) project to develop an alternative approach to teaching whole numbers and operations that includes certain central RME ideas. This project is a central reference in the mathematical domain of number in Portugal. Here the fundamental

\footnotetext{
${ }^{1}$ Koeno Gravemeijer has been at EIEM in 1997 (Castelo de Vide), Marja van den Heuvel-Panhuizen at CIEAEM in 1997 (Setúbal), Rijkje Dekker, Koeno Gravemeijer and Jean-Marie Kraemer at 'Mathematics Education: Paths and Crossroads in Memory of Paulo Abrantes' in 2005 (Lisbon), and Henk van der Kooij at EIEM in 2006 (Monte Gordo).

${ }^{2}$ Especially Koeno Gravemeijer and Jean-Marie Kraemer.

${ }^{3}$ Association of Mathematics Teachers.
} 
influences can be identified related to the role of counting, place value and standard algorithms, the role of the context of tasks and the use of models in mathematics learning.

Also in this perspective, in a book published by the Portuguese Ministry of Education to support the activity of infant education teachers, Castro and Rodrigues (2008) indicated that children may use counting to compute. From a sequence of tasks, they exemplified how the activity of counting may evolve from one to one counting to the re-invention of informal mental strategies based on counting, one of the RME big ideas (Beishuizen \& Anghileri, 1998). Still in the same vein, Rodrigues (2010), in a study addressing the development of number sense in children from three infant schools, concluded that it is from the numerical sequence and from counting competences that children develop other numeral competences. The children that she studied used counting as an informal strategy that, based in diversified experiences in meaningful numerical contexts, was progressively structured, discovering counting in patterns and jumps.

\subsubsection{Place Value and Standard Algorithms}

The tradition of focussing numerical learning in the early use of place value aiming at the quick construction of standard algorithms was strongly questioned by several RME authors. Brocardo, Serrazina and Kraemer (2003), following this trend and basing their argumentation on authors such as Gravemeijer (1991) and Fosnot and Dolk (2001a) highlighted the need to link structurally the development of computation methods and techniques to the construction of numbers, their organisation and structure. In order to achieve this, all these authors argued that it is necessary to delay the learning of algorithms the early introduction of which they viewed as hindering an adequate development of number sense. Brocardo and Serrazina (2008), reflecting on the work carried out by the DNS project, strongly influenced by Gravemeijer (1991, 1994, 2005), Treffers $(1987,1991)$ and Buys (2008) on the teaching and learning of numbers and operations, suggested that the algorithms must not be the central focus of the curriculum, and that students must learn them in a long journey based in developing number sense.

Two teaching experiments carried out as doctoral theses underscore this perspective. In the first, carried out in a Grade 2 class, Ferreira (2012) was strongly inspired by the notion of landscape of learning of Fosnot and Dolk (2001a, b) in which students were invited to construct their ideas and strategies based on the analysis and manipulation of numbers as a whole. As proposed by RME, this teaching experiment did not include explicit references to place value and emphasised a holistic approach to number, with the development of 'horizontal' written calculation strategies. The author concluded that the four students studied managed to solve the proposed addition and subtraction problems without using the standard algorithm. Instead, they began to reason arithmetically, using familiar relations between numbers and between addition and subtraction, as indicated by Blöte, Van der Burg, and Klein (2001) and Gravemeijer (2005). 
In another teaching experiment, in a Grade 3 class, Mendes (2012) got support on the theoretical ideas of Fosnot and Dolk (2001b) related to multiplication. The big ideas that Mendes assumed in her work included unitizing (numbers are used to count not only objects but also groups), the distributive property (realising that $7 \times$ 5 can be solved by adding $5 \times 5$ and $2 \times 5$, or any combination of groups that add up to seven groups), the associative property $(2 \times\{5 \times 9\}=\{2 \times 5\} \times 9)$ and the commutative property $(52 \times 2=2 \times 52)$.

\subsubsection{The Role of the Context of Tasks and the Use of Models and Manipulative Materials}

The influence of RME ideas regarding the context of tasks inspired the production of classroom materials in the DNS project (Brocardo et al., 2005; Brocardo \& Serrazina, 2008) and of research studies (such as Delgado, 2013; Mendes, 2012; Rodrigues, 2010). In these studies, the context of tasks was carefully planned as a starting point and source for modelling. Attention was paid to the clarity of the written text, to the accompanying images that should not be simple illustrations, and to how the task might arouse students' curiosity. Explaining the way the project team thought about the context of tasks, Brocardo and Delgado (2009) underlined the idea of Freudenthal (1968) that mathematics must be learned as a process of mathematising reality and, if possible, in the process of mathematising mathematics itself. They also indicated the important characteristics of the context of tasks so that it would become a situation that lends itself to mathematising, as Fosnot and Dolk (2001b) suggested-to allow the use of models, to make sense for students, to create surprise and arouse questions.

The tasks with contexts that appeal to models are one of the RME influences that it is possible to identify in many research studies carried out in Portugal (such as Delgado, 2013; Ferreira, 2012; Mendes, 2012). An example is the 'Drinks machine' task (Brocardo et al., 2005), inspired by a task developed by Kraemer and Paardekooper (1998) in which cans with drinks of different flavours are put in a machine with a maximum capacity of twenty cans for each variety. There are horizontal limits that organise the stacks of cans in groups of five, allowing for connections with the string of beads and the empty number line model structured from five in five (Fig. 12.1).

The exploration of contexts such as fruit boxes or tile tessellations are paradigmatic examples of contexts associated with the rectangular model widely used to structure multiplication. Another example was provided by Rocha and Menino (2009) who presented a task chain inspired by Fosnot and Dolk (2001b) with an underlying progression aimed at using the rectangular model in successive phases of abstraction. To achieve that, the context used began by allowing a counting of the objects that are all visible (fruits shown on a box), then allowing to count all the objects of a half of a rectangular array (two equal curtains in which one has all patterns visible and the other does not), and, finally, situations in which counting was discouraged by covering part of the rectangular patterns with objects or people leading students to think in terms of lines and columns and begin to use the rectangular model, thus leaving addition and using multiplication. 
Fig. 12.1 The drinks machine (Brocardo et al., 2005)

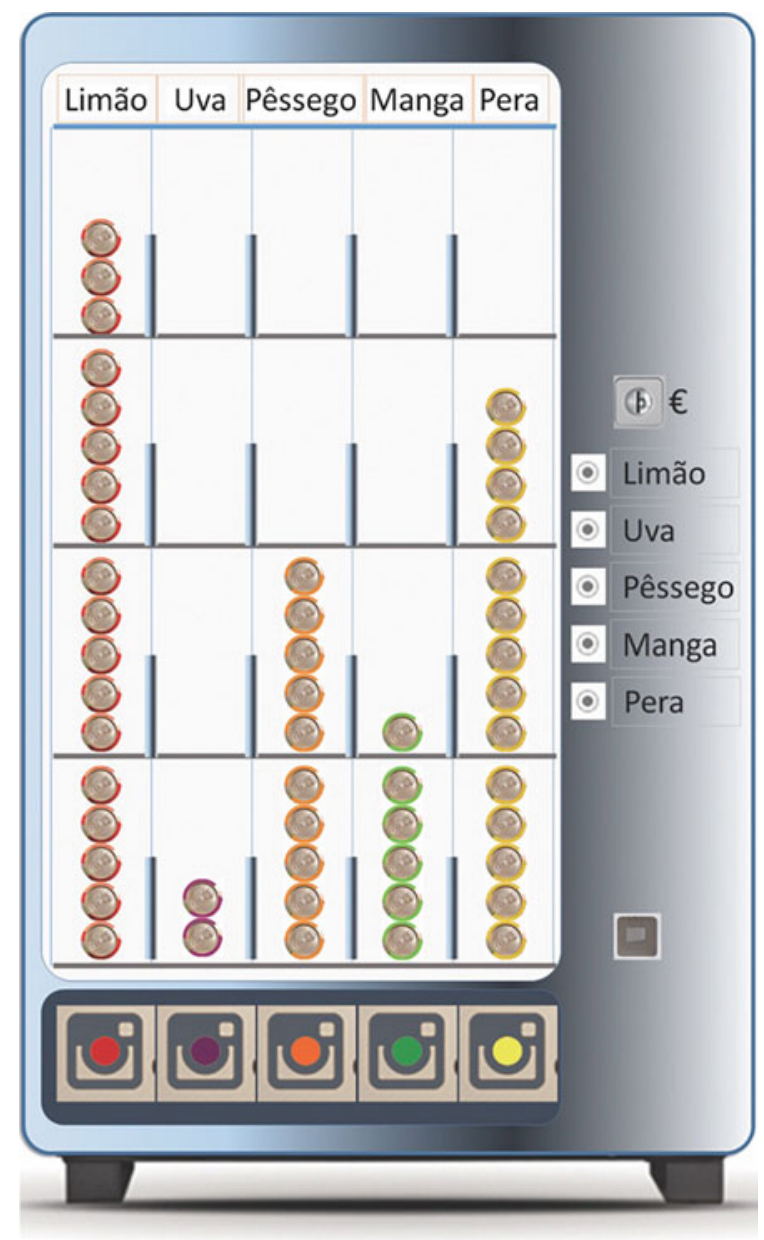

Mendes (2012) used this type of contexts in her research focussed on learning of multiplication, and in the design of the sequence of tasks, she sought that the numbers involved, carefully framed from task to task, would appeal to multiplicative numerical relationships, as suggested by Treffers and Buys (2008) (Fig. 12.2).

The results of this research indicated that the chosen context for the multiplication tasks contributed to consolidating the use of multiplicative procedures. She also concluded that students who established connections among the contexts and the numbers of sequential tasks constructed procedures based on that relationship, and there were multiplicative procedures used by students (such as the use of relationships involving doubling) that were induced by the numbers used in the tasks. In her study, focussed on the practices of two teachers, Delgado (2013) concluded that in an initial phase of the study the teachers mainly valued contexts of tasks that were close to 


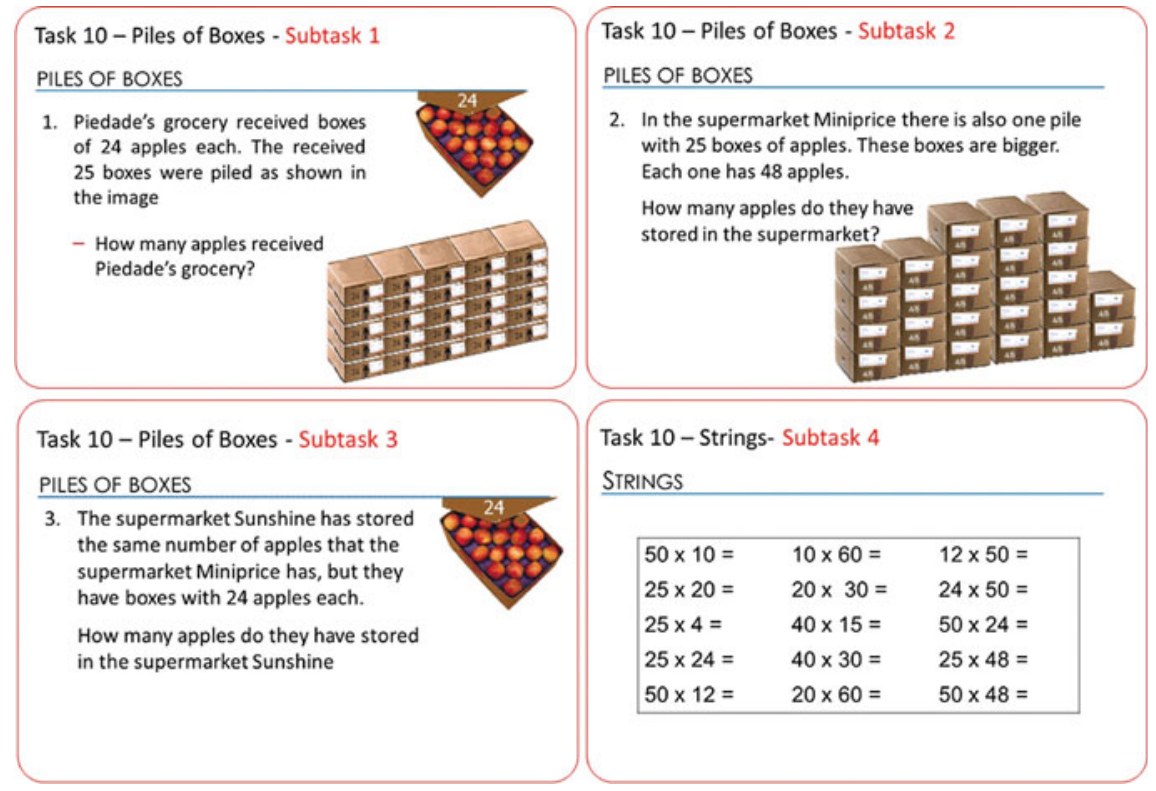

Fig. 12.2 Example of one multiplicative context used by Mendes (2012)

students' daily life situations, to motivate them and lead them to engage in solving the tasks. As the study progressed, the teachers also began to recognise the importance of contexts in developing meaning for the numbers and operations associated with them, as underlined by Fosnot and Dolk (2001b) when referring to the characteristics of the contexts of tasks that foster the development of number sense.

In Portugal, there is not a strong tradition of using manipulative materials, despite the fact that all official curricula since 1975 refer to the importance of manipulating objects and using structured materials such as MAB or the abacus. RME influenced a reflection on the use of such materials, in contrast with the use of models, in particular the empty number line. Brocardo et al. (2005) made a detailed analysis of the potential of the empty number line, and followed RME perspectives in reflecting on the potential and limitations of MAB. They argued that usual materials for learning computation with whole numbers are often difficult for many students, provide few opportunities for the use of informal strategies, and do not promote the evolution of mental computation strategies. Brocardo and Serrazina (2008) referred to the comparison that Beishuizen (2001) made between the use of the one hundred square and the empty number line, highlighting the importance that the model must lead the students to think in the strategy that they use and the computations that they do. Therefore, they criticised the use of the one hundred square because it is possible to calculate using mechanical procedures such as "add 10 is to come down one line and read the number" or "take away 5 is to move 5 numbers backwards and see where we stop" that allows to arrive at a result doing no thinking at all. Several 
tasks produced in the DNS project discuss the advantages of the empty number line, indicating that its use enables children to have an image of jumping forwards and backwards keeping the multiples of ten as landmarks and thinking in numbers and their relations, calculating with the head. Use of the empty number line began to spread since 2005 and was recommended for the first time in an official curriculum of the Ministry of Education (Ministério da Educação, ME, 2007). In later research studies focussed on teaching and learning numbers and operations (such as Delgado, 2013; Ferreira, 2012) and in some textbooks, the use of the empty number line model became usual.

\subsubsection{Mental Calculation}

The concept of mental arithmetic referred to by Buys (2008) and widely used in the Netherlands gained certain acceptance in Portugal. Brocardo and Serrazina (2008) indicated that for the DNS project mental calculation implied dealing with number values (not with digits), using elementary calculation properties and number relationships, and allowing for the possible use of suitable intermediate written notes. This notion aligns well with that of Buys and is adopted by many other Portuguese researchers. Several booklets edited by the Portuguese Ministry of Education to support the implementation of the 2007 Portuguese mathematics curriculum adopted this concept of mental calculation and exemplified it with appropriate tasks for how it can be developed.

Several studies were undertaken in the last decade focussing on the development of mental calculation. These studies emphasised the development of mental calculation strategies supported by a careful articulation of sequences of tasks (for example, Delgado, 2013; Ferreira, 2012; Mendes, 2012; Pinto, 2011). Following RME perspectives, these authors considered the written methods as specific developments of the mental strategies that children learn, which should be organised in a continuous progression. To ensure that this development happens, it is important that students learn to use mental calculation strategies in a flexible way. These strategies may be organised in three big groups: (i) stringing strategies, in which the operations are movements along the counting row, (ii) splitting strategies, in which operations are performed by splitting and processing the numbers based on the ten's structure; and (iii) varying strategies, based on arithmetic properties.

The teaching experiment conducted by Mendes (2012) included several mini lessons with mental mathematics strings (as suggested by Fosnot \& Dolk, 2001a, b). This researcher concluded that the articulation between the numbers used in the problems and the numbers used in the mental mathematics strings was important since students were able to adapt from each other the procedures that they used. She also concluded that the numbers used in the mental mathematics strings and the way they were constructed enabled students to use numerical relationships based on multiplication properties. The studies of Pinto (2011), Ferreira (2012), Mendes (2012) and Delgado (2013) provided evidence that an approach to mental calculation 
that articulates the knowledge of number facts and strategic methods has big potential to develop students' numerical competences. In fact, the students studied evolved in a significant way, using adequate strategies, and in many cases flexibly adapted to contexts and numbers.

Brocardo (2011) proposed the setting up of goals for mental calculation to attain at the end of each school cycle based on the distinction of three categories of mental calculation proposed by Buys (2008). Referring to ideas of the TAL team, ${ }^{4}$ she indicated that this distinction demystifies the idea that such calculation cannot include written notes, and clarified that mental calculation is not just automatic calculation. She also presented a proposal for the development of mental calculation that included several RME ideas. Underlining that mental calculation work must be systematic and intentional, she exemplified that mental mathematics strings (Fosnot \& Dolk, $2001 \mathrm{a}, \mathrm{b}$ ) may contribute to constructing basic numerical knowledge important for the development of mental calculation strategies from Grades 6 to 12. Brocardo (2011) proposed exploring open tasks, in which students discover interesting numerical patterns that may lead to efficient calculation techniques that students get for their use. She also suggested that systematic work in constructing a web of relationships, as recommended by Kraemer and Van Benthem (2011). Such a web is based on the idea of beginning from a known fact such as $4 \times 5$ is 20 and constructing all multiplicative relations connected to it. In her proposal, Brocardo (2011) emphasised that the teacher has a key role in selecting tasks that arouse students' curiosity and leading them to develop mental calculation, in distinguishing situations in which it is appropriate to use the calculator from those in which that does not make any sense and in assuring that students use mental calculation always when appropriate.

\subsubsection{Rational Numbers}

Teaching and learning rational numbers has attracted significant attention from Portuguese researchers in mathematics education, with two particularly noticeable influences - from the Rational Number Project (Behr, Harel, Post, \& Lesh, 1992) and from RME. We analyse here the influence of RME.

\subsubsection{Mapping Students' Difficulties}

In a literature review on teaching and learning rational numbers that has been an important reference for research on this topic in Portugal, Monteiro and Pinto (2006) discussed students' difficulties in working with fractions and their strategies in solving problems. The presense of RME ideas is particularly noticeable in the point

\footnotetext{
${ }^{4}$ The TAL team was responsible for developing a teaching-learning trajectory for calculation with whole numbers in primary school (Van den Heuvel-Panhuizen, 2008). Kees Buys was one of the members of this TAL team.
} 
on students' strategies, as the authors underlined the idea that mathematics must be reinvented by students in a progressive process of generalisation and formalisation (De Lange, 1996; Gravemeijer, 1991, 1997; Streefland, 1986, 1991; Treffers, 1991). Monteiro and Pinto (2006) indicated that, in the perspective of RME, students' learning is based on informal strategies for solving tasks, from which they develop concepts and connections among concepts, in a mathematising process. They also referred to horizontal mathematising and to modelling of real situations through the use of symbols as well as to vertical mathematising as a path internal to mathematics (Gravemeijer, 1997). Monteiro and Pinto (2006) presented the ideas of Keijzer (2003) regarding mathematising processes (modelling, symbolisation, generalisation, formalisation and abstraction). They pointed out that, to bridge the gap between concrete and abstract, students need tools such as visual models, schemas, and diagrams that work for them as supports for thinking (Streefland, 1993). They also indicated that symbols may become objects of thinking, constituting images for more abstract levels of understanding (Streefland, 1991).

Monteiro and Pinto (2006) recalled the ideas of Streefland (1986) about the algebraic structure of rational numbers being the support for the most common view on the teaching of fractions. In their perspective, that explains why operations appear in the Portuguese curricula in a given order and why the algorithms to compare, add and multiply fractions have so much weight. They considered that it is the role of the teacher to provide students with opportunities to reinvent mathematics, instead of seeking to make accessible to them 'ready-made' mathematics.

\subsubsection{Use of Representations and Models}

Based on a teaching experiment, Ponte and Quaresma (2011) studied the development of Grade 5 students' understanding of the notion of rational number, ordering and comparing rational numbers, and equivalence of fractions. In this study, a fundamental idea was the simultaneous use of different representations, as well as of different meanings, kinds of magnitudes, and kinds of task. The authors referred to the 'iceberg model' of representations of Boswinkel (see Webb, Boswinkel, \& Dekker, 2008) that suggests that students need a large amount of experience with different informal and preformal representations as a basis to construct a meaning for formal mathematical representations. In this way, the students used pictorial representations as a support for their work with the more formal representations of decimal numerals, fractions, percentages, and mixed numerals. Based on ideas from Streefland (1991), who underlined that the work on fractions must be done based on their names, such as 'a half', 'a third', 'a quarter', and so on, the authors considered that verbal representation, which is sometimes neglected in research, fulfils a fundamental role in the work with rational numbers, notably in oral communication. In addition, echoing ideas from Gravemeijer (2005), through all the teaching unit, as a starting point for constructing concepts, they valued the students' intuitive and informal strategies as well as their prior knowledge. In their results, they pointed out that students tend to begin by using simultaneously verbal and pictorial representa- 
tions that enable the interpretation of the information in the statement of the task and support the reasoning to get to the solution.

The study of Ventura (2014), carried out with Grade 5 students, aimed to understand their evolution in learning the concept of rational number, based on a teaching experiment that was based essentially on the use of the numerical bar and the numerical line, and at the same time to ascertain the potential of this approach. In this study, the notion of model (based on Van den Heuvel-Panhuizen, 2003), fulfilled a key role as a representation of a problematic situation that reflects essential aspects of the mathematical concepts and that, therefore, constitutes a tool for solving problems. Ventura concluded that the students evolved in their learning of the concept of rational number, and indicated that, as a problem-solving strategy, many of them began to use the numerical bar as a 'model of', and later used it as a 'model to' reason (Gravemeijer, 2005; Streefland, 2003).

Guerreiro and Serrazina (2014) also studied students' strategies in solving problems involving rational numbers, but in this case in Grade 3. They based themselves on the perspectives of Fosnot and Dolk (2002) that indicate that students must understand important ideas and progressively refine their strategies in order to make them more efficient. Guerreiro and Serrazina assumed as central the notion of mathematical model, regarded as a tool for problem solving, and referred to examples such as "ratio tables, double numerical lines, clocks, grids and percent bars" (Fosnot \& Dolk, 2002, p. 83). In the perspective of Guerreiro and Serrazina, these models may support students in generalising, going beyond what is specific in each situation. Building on ideas of Fosnot and Dolk (2002) and Gravemeijer (2005), Guerreiro and Serrazina considered that models emerge from situations experienced by students that evolve towards mathematical models of numerical relationships, becoming mathematical tools.

In other studies involving teaching and learning rational numbers in several grade levels, Ponte and Quaresma (2011, 2014b), Quaresma and Ponte (2012) and Guerreiro and Serrazina (2015), also based themselves on the model of different levels of mathematical activity of Gravemeijer (2005) and on the iceberg model of Boswinkel (Webb et al., 2008) to indicate the need for working from contexts meaningful for students and to assume that, in a first phase, an emphasis must be placed on informal representations that students already know, in order to introduce then, gradually, more formal new representations and working processes with rational numbers.

\subsubsection{Learning Multiplication and Division}

The study of Pinto (2011) analysed the development of the multiplication and division sense in Grade 6 students in working with rational numbers through a teaching unit. This unit involves the exploration of multiplication and division of rational numbers in meaningful contexts, based on RME principles. The unit values solving problems with contexts meaningful for students, their written productions, the development of models of the situations, the mathematical connections, the interactions in the classroom, and formative and regulatory evaluation. Underlying this unit is a 
hypothetical learning trajectory for multiplication and division of rational numbers that emphasises the development of multiplicative reasoning and operation sense in an integrated way. Building on RME researchers (such as Fosnot \& Dolk, 2002; Freudenthal, 1973, 1983, 1991; Treffers, 1987, 1991; Treffers \& Goffree, 1985), Pinto assumed that the study of rational numbers in school must begin based on fair sharing contexts related to students' reality and be oriented towards a constructive mathematising process. She also valued ratio problems (quoting Streefland, 1991, 1993) and suggested ratio tables as models for comparing fractions, especially in the case of fractions that are difficult to compare without applying rules. She noted, however, that students need to work with the other meanings of fractions (ratio, partwhole, measure and operator). In her analysis, she also assumed an important role for the notion of model as a learning support in moving from concrete to abstract knowledge (Van den Heuvel-Panhuizen, 1996, 1998; Van den Heuvel-Panhuizen \& Wijers, 2005). The results of the study indicated that the students develop a sense for the multiplication and division of rational numbers, showing familiarity with different meanings and contexts of operations, flexibility in the use of proprieties of operations, critical ability in the analysis of processes and results, and capacity to use symbols and formal mathematical language with meaning.

\subsubsection{Algebra}

In the last ten years, algebra has attracted much attention in mathematical education research in Portugal. This investigation is mainly influenced by the ideas of Carpenter, Kaput, Kieran and Radford concerning the development of algebraic thinking. Nevertheless, influences deriving from RME have also been noted. For example, in an article for mathematic teachers, Ponte, Branco, and Matos (2008) analysed the role played by symbols in the development of students' algebraic thinking. The authors presented the perspective of Freudenthal (1983) concerning the teaching of algebra, indicating that "the symbols must mean something, at least initially, by analogy to what happened in the historical development of algebra" (Ponte et al., 2008, p. 90). They underline the importance of the process of progressive formalisation and also presented Freudenthal's perspective concerning algebraic language as a system framed by syntactic rules, which allow for the development of certain actions and highlights that the complexity of the algebraic language may originate incorrect interpretations from students.

In their study, Pereira and Saraiva (2013), proposed a learning and teaching model based on the notion of the parameter of a function to structure the mathematical reasoning of secondary school students in Grade 11. This model analyses the students' concepts, concerning relevance, cohesion and algebraic coherence, with teaching organised in three levels: reference operational, informal operational, and structural operational. For the authors, the concepts are structured at each level, representing contexts that promote the creation of meanings in a hierarchical logic. This work showed the influence of Gravemeijer's perspective of levels of students' mathemat- 
ical activity (2005) in the construction of tasks in a teaching experiment, with the reference operational level matching the 'model of' level, the informal operational level matching the 'model to' level, and the structural operational level matching the formal level. According to Pereira and Saraiva, the results of their study suggest that this model is useful to structure tasks to promote students' thinking and to develop students' reasoning with mathematical concepts.

In an investigation carried out with Grade 4 students, intended to understand how to promote their relational thinking, Mestre and Oliveira (2013) focussed on the issue of the context and its connection to representations. They gave special attention to the way the teacher orchestrates the whole class discussion of a mathematical task and guides the systematisation of learning. For the authors, the tasks have an important role, with special emphasis on their contexts that must be significant to promote the development of students' relational thinking. Supported by Gravemeijer and Doorman (1999), the authors considered that contextualised problems constitute a source for mathematical activity, allowing the transition from informal to formal strategies. They also indicated that as students experiment with the process of reinventing mathematics through solving contextualised problems, they develop their mathematical knowledge and broaden their understanding of the real world. On this matter, the authors underlined the reflexive relation between the utilisation of contextualised problems and the apprehension of reality, arguing that these problems have roots in this reality and their solution helps students to broaden their own notion of reality. They concluded that the students used several representations, successfully presenting the values of the variables in the algebraic symbolic form.

The development of students' mathematical reasoning is an issue that has been studied in Portugal, mainly in studies related to the learning of algebra and also of rational numbers. Ponte, Mata-Pereira, and Henriques (2012), Mata-Pereira and Ponte (2013) and Ponte and Quaresma (2014a) regarded mathematical reasoning as the process of formulating inferences in a justified way, considering that this involves deductive, inductive and abductive aspects. In their view, justification is the central process of deductive thinking and generalisation is the central aspect of inductive and abductive reasoning. One of the main ideas of these studies is that reasoning is strictly connected to the representations used, which may assume a more formal or informal nature. In a study carried out with Grade 5 students, Ponte and Quaresma (2014a) presented a model that distinguishes between formal reasoning with and without understanding, where formal reasoning with understanding is based on informal reasoning, in a back and forth process, while formal reasoning without understanding relies essentially on memorised learning. This perspective on mathematical reasoning assumes that the big problem in teaching this subject is knowing how to make the progressive articulation between formal and informal reasoning processes and is supported by Gravemeijer's (2005) model of levels of mathematical activity.

In other research reports involving the teaching and learning of algebra, the influence of the RME authors is also visible. For example, Ponte (2005), in an article discussing the approach to algebra in the school curriculum, pointed to the role of 'real situations' in learning, making reference to the work of De Lange (1993). Pimenta and Saraiva (2013), in research aimed at the development of the algebraic 
thinking of Grade 4 and 5 students, referred to Freudenthal's notion of vertical mathematising (1973). And Silvestre and Ponte (2012), in a study of the development of the proportional reasoning of Grade 6 students, mentioned Gravemeijer's (2005) model of levels mathematical activity.

\subsubsection{Geometry}

In contrast to numbers and algebra, geometry is a mathematical topic that has attracted less attention from Portuguese mathematics education research. At an early stage, in the 1980s, the model of Van Hiele's (1984) levels of geometrical reasoning played an important role, especially in the work of Matos (1984), who studied the geometric thinking ability of prospective early-years teachers. However, in recent years, there is no record of references based on this model of geometric thinking. In today's Portuguese work on geometry the most visible influences are those of American authors such as Battista and Clements. However, there are also echoes of RME ideas, especially with regard to general perspectives on the teaching of geometry.

Pinheiro and Carreira (2013) discussed the development of geometric reasoning in the context of the use of Geogebra in a teaching experiment with Grade 7 students in order to know how they develop their understanding of the properties and relationships of geometric figures in studying triangles and quadrilaterals. In formulating their educational perspective, Pinheiro and Carreira presented the ideas of Freudenthal $(1971,1991)$ on the role of geometry in the school curriculum and on the teaching of geometry. Hence, the authors emphasised the role of geometry, given its importance to understand and organise spatial phenomena and they assumed that teaching should focus on the construction of conceptual models. They also valued the importance of manipulating physical materials in specific situations. Furthermore, they found that deductive reasoning should be promoted in accordance with students' maturity and that the most suitable way to learn geometry is "to allow the pupil to gradually become aware of their intuitive understanding of space" (Pinheiro \& Carreira, 2013, p. 148). The results of this study showed that the sequence of tasks built and the way that the tasks were solved in the classroom helped to promote students' understanding of the mathematical concepts involved. They also found that the use of the dynamic geometry environment contributed to the development of students' spatial reasoning ability, and therefore of their geometric reasoning.

In another study, Mestrinho and Oliveira (2012) analysed how the use of the tangram may support understanding of the area concept in prospective early-years teachers, as part of a teacher education experiment in the second year of the programme. The authors referred to the idea of Freudenthal (1983), according to which the concept of area is much more complex than the concept of length, since the definition of an equivalence relation and of an order relation as well as the creation of a composition operation are much more complex for area. They also showed three perspectives on the concept of area referred to by Freudenthal (1983), namely 'equitable distribution' (situations in which it is necessary to divide a figure into equivalent 
parts), 'comparison and reproduction' (situations that involve the comparison of two parts of a surface or the reproduction of a certain amount of area with a different shape), and 'measurement' (situations involving filling a part of a surface with congruent figures, decomposition and recomposition operations or the use of general geometric relationships). The authors found that the use of the tangram as a resource promotes the development of basic ideas for understanding of area measurement, and allows to explore different approaches to this concept.

\subsection{Influences on Curriculum Documents}

Abrantes (1994) studied how an innovative curriculum developed by the project $\operatorname{MAT}_{789}{ }^{5}$ influenced the ability and disposition of students to tackle problems involving relationships of mathematics with reality and the way they saw mathematics and mathematics learning. In this experimental curriculum, there are two clear influences of RME: the perspectives about how to conduct curriculum development and how to frame evaluation processes. On a small scale the work of Abrantes is similar to the Dutch approach to curriculum development through projects such as carried out at OW\&OC, ${ }^{6}$ the predecessor of the Freudenthal Institute, or the curriculum development that was done in collaboration with SLO, Netherlands Institute for Curriculum Development. Characteristics of this curriculum development was that successive versions of materials were trialled, evaluated, and modified before being generalised. Abrantes (1994) referenced that regarding evaluation, the major influence came from the $\mathrm{HEWET}^{7}$ project (De Lange, 1987) - in which teaching materials were developed on various mathematical topics for pre-university education-and highlighted the concern that evaluation must generate learning situations, be consistent with aims and methodologies, have a positive nature, and occur in a climate of trust and clarity.

At the national level, the mathematics curriculum for basic education (ME, 2007) shows a clear influence of RME ideas, notably in the topic of numbers and operations. An important methodological guideline is the informal use of counting that evolves through replay and repetition to become structured knowledge. For example, the mathematics curriculum for basic education indicates that

the exploration of counting processes used by students associated with different possibilities to structure and relate numbers, contributes to the understanding of the first numerical relationships. These relationships are fundamental to understand the arithmetic operations and, besides, are a foundation for the development of number sense. (ME, 2007, p. 14)

\footnotetext{
5 A project that developed and tested an innovative curriculum for students aged 12 to 15 years carried out by Paulo Abrantes, Eduardo Veloso, Leonor Santos, Paula Teixeira, and Margarida Silva.

6 Onderzoek Wiskundeonderwijs en Onderwijs Computercentrum (Mathematics Education Reasearch and Educational Computer Centre).

${ }^{7}$ Herverkaveling Wiskunde I en II (Re-allotment Mathematics I and II); the HEWET project resulted in Mathematics A and Mathematics B, a new mathematics curriculum for the upper grades (age 16-18) of VWO, the pre-university level of secondary education.
} 
This curriculum does not integrate the RME approach to written calculation in number operations, but it recognises the importance of delaying the introduction of the standard algorithms and stresses the idea that it is important to progressively develop more high-level abbreviated strategies. This document also recommends the use of the empty number line as a model that can be used alongside others. In addition, for teaching all topics, this curriculum stresses the importance of working from tasks posed in meaningful contexts, highlighting the importance of contexts that may engage students in asking questions, notice patterns, and lead them to use mathematical models and adequate representations.

\subsection{Conclusion}

As indicated in this chapter, many RME authors have influenced Portuguese mathematics education. The most salient are, in a first phase, Freudenthal, Treffers and Streefland, and, in more recent times, Gravemeijer, Van den Heuvel-Panhuizen, Fosnot and Dolk and Buys. Such influences can be seen in many mathematical fields, from numbers and operations to algebra and geometry, often mixed with influences from other mathematics education research programmes. The influences concern RME general ideas such as the perspective about representations and the notion of model and the levels of mathematical activity with attention to the progressive refinement of students' strategies from informal towards formal levels. There are also frequent references to the processes of vertical and horizontal mathematising and to the use of experientially real situations as a basis for learning.

The importance of carefully formulating the contexts of tasks as well as the articulation among them stands in studies related to numbers and operations. Tasks and the work that is done based on them in the classroom must favour the transformation of students' reasoning and mental calculation processes, from informal towards progressively more formal levels, and support the development of mathematical concepts. The importance of algebraic language as well as the process of progressive formalisation stands in studies regarding the teaching and learning of algebra. In the case of geometry, RME influences concern the importance of this topic in the curriculum and the didactical approach, underlining the role of the manipulation of materials, as well as the phenomenological analysis of concepts. There are several other fields in which Portuguese research comes close to RME ideas, such as the use of technology as a support for students' learning, organising teacher education with a strong connection to practice, and framing studies as design-based research; however, in these cases, the most quoted authors are usually from other approaches.

In several crosscutting topics, we also see RME influences. The mathematical tasks used in most recent research studies in Portugal strive to be framed in interesting contexts and to allow for a wide variety of students' solutions. The sequences of tasks constructed in these studies indicate possible learning routes, supporting a process of progressive mathematising, an important RME principle. Didactical phenomenology, another important RME idea, is also present in several research studies, in which 
a given mathematical topic is explored in depth, with great attention to everyday situations in which it can be traced. At another level, we may say that the pragmatic spirit of RME, and its concern for improving mathematics education by working in close connection with teachers and schools is also present in studies undertaken in our country. Globally, the work developed by Portuguese researchers using RME notions and tools has proven to be fruitful and underscores the value of the results and ideas of RME perspectives. In addition, these perspectives have been an important support for the development of research in mathematics education in Portugal, with positive effects on teachers' professional practices and, we believe, on students' learning.

\section{References}

Abrantes, P. (1994). O trabalho de projecto e a relação dos alunos com a Matemática: A experiência do projecto $M A T_{789}$ [Project work and the relation of students with mathematics: The experience of the project $\mathrm{MAT}_{789}$ ] (Doctoral thesis). Lisbon, Portugal: University of Lisbon.

Behr, M., Harel, G., Post, T., \& Lesh, R. (1992). Rational number, ratio and proportion. In D. Grouws (Ed.), Handbook of research on mathematics teaching and learning (pp. 296-333). New York, NY: Macmillan.

Beishuizen, M. (2001). Different approaches to master mental calculation strategies. In J. Anghileri (Ed.), Principles and practices in arithmetic teaching (pp. 119-130). Buckingham, UK: Open University Press.

Beishuizen, M., \& Anghileri, J. (1998). Which mental strategies in the early number curriculum? A comparison of the British ideas and Dutch views. British Educational Research Journal, 24(5), $519-538$.

Blöte, A. W., Van der Burg, E., \& Klein, A. S. (2001). Pupils' flexibility in solving two-digit addition and subtraction problems: Instruction effects. Journal of Educational Psychology, 93, 627-638.

Brocardo, J. (2011). Uma linha de desenvolvimento do cálculo mental: Começando no $1 .^{\circ}$ ano e continuando até ao $12 .^{\circ}$ ano [A line of development of mental computation: Beginning at grade 1 and going on up to grade 12]. In Atas do ProfMat 2011. Lisbon, Portugal: APM.

Brocardo, J., \& Delgado, C. (2009). Desafios e complexidades na concepção e exploração de tarefas para o desenvolvimento do sentido do número [Challenges and complexity in the conception and exploration of tasks for the development of number sense]. In C. Costa, E. Mamede, \& F. Guimarães (Eds.), Actas do XIX EIEM. Secção de Educação Matemática da Sociedade Portuguesa de Ciências da Educação: Vila Real.

Brocardo, J., Delgado, C., Mendes, F., Rocha, I., Castro, J., Serrazina, L., \& Rodrigues, M. (2005). Desenvolvendo o sentido do número [Developing number sense]. In Equipa do projecto DSN (Eds.), Desenvolvendo o sentido do número: Perspetivas e exigências curriculares (pp. 7-27). Lisbon, Portugal: APM.

Brocardo, J., \& Serrazina, L. (2008). O sentido do número no currículo de Matemática [Number sense in the mathematics curriculum]. O sentido do número: Reflexões que entrecruzam teoria e prática (pp. 97-115). Lisbon, Portugal: Escolar Editora.

Brocardo, J., Serrazina, L., \& Kraemer, J.-M. (2003). Algoritmos e sentido do número [Algorithms and number sense]. Educação e Matemática, 75, 11-15.

Buys, K. (2008). Mental arithmetic. In M. van den Heuvel-Panhuizen (Ed.), Children learn mathematics: A learning-teaching trajectory with intermediate attainment targets for calculation with whole numbers in primary school (pp. 121-145). Rotterdam, the Netherlands: Sense.

Castro, J., \& Rodrigues, M. (2008). Sentido de número e organização de dados [Number sense and data organisation]. Lisbon, Portugal: DGIDC. 
De Lange, J. (1987). Mathematics, insight and meaning. Utrecht, the Netherlands: OW\&OC, Utrecht University.

De Lange, J. (1993). Innovation in mathematics education using applications: Progress and problems. In J. de Lange, C. Keitel, I. Huntley, \& M. Niss (Eds.), Innovation in maths education by modelling and applications (pp. 3-18). New York, NY: Ellis Horwood.

De Lange, J. (1996). Using and applying mathematics in education. In A. J. Bishop, K. Clements, C. Keitel, J. Kilpatrick, \& C. Laborde (Eds.), International handbook of mathematics education (Vol. 1, pp. 49-98). Dordrecht, the Netherlands: Kluwer.

Delgado, C. (2013). As práticas do professor

e o desenvolvimento do sentido de número: Um estudo no $1 .{ }^{\circ}$ ciclo [Teacher practices and the development of number sense] (Doctoral thesis). Lisbon, Portugal: University of Lisbon.

Ferreira, E. (2012). O desenvolvimento do sentido de número no âmbito da resolução de problemas de adição e subtração no $2 .^{\circ}$ ano de escolaridade [The development of number sense in solving addition and subtraction problems at grade 2] (Doctoral thesis). Lisbon, Portugal: University of Lisbon.

Fosnot, C. T., \& Dolk, M. (2001a). Young mathematics at work: Constructing number sense, addition and subtraction. Portsmouth, NH: Heinemann.

Fosnot, C. T., \& Dolk, M. (2001b). Young mathematics at work: Constructing multiplication and division. Portsmouth NH: Heinemann.

Fosnot, C. T., \& Dolk, M. (2002). Young mathematicians at work: Constructing fractions and percents. Portsmouth, NH: Heinemann.

Freudenthal, H. (1968). Why to teach mathematics so as to be useful? Educational Studies in Mathematics, 1, 3-8.

Freudenthal, H. (1971). Geometry between the devil and the deep sea. Educational Studies in Mathematics, 3, 413-435.

Freudenthal, H. (1973). Mathematics as an educational task. Dordrecht, the Netherlands: Reidel.

Freudenthal, H. (1983). Didactical phenomenology of mathematical structures. Dordrecht, the Netherlands: Kluwer.

Freudenthal, H. (1991). Revisiting mathematics education: China lectures. Dordrecht, the Netherlands: Kluwer.

Gravemeijer, K. P. E. (1991). An instruction-theoretical reflection on the use of manipulatives. In L. Streefland (Ed.), Realistic mathematics education in primary school (pp. 57-76). Utrecht, the Netherlands: Freudenthal Institute.

Gravemeijer, K. P.E. (1994). Developing realistic mathematics education. Utrecht, the Netherlands: CD- $\beta$ Press/Freudenthal Institute, Utrecht University.

Gravemeijer, K. P. E. (1997). Mediating between concrete and abstract. In T. Nunes \& P. Bryant (Eds.), Learning and teaching mathematics: An international perspective. Hove, UK: Psychology Press.

Gravemeijer, K. P. E. (2005). What makes mathematics so difficult, and what can we do about it? In L. Santos, A. P. Canavarro, \& J. Brocardo (Eds.), Educação matemática: Caminhos e encruzilhadas (pp. 83-101). Lisbon, Portugal: Associação de Professores de Matemática (APM).

Gravemeijer, K. P. E., \& Doorman, M. (1999). Context problems in realistic mathematics education: A calculus course as an example. Educational Studies in Mathematics, 39, 111-129.

Guerreiro, H. G., \& Serrazina, L. (2014). Contributos de um projeto de turma para o design de tarefas [Contributions of a class project for the design of tasks]. In J. Brocardo, A. M. Boavida, C. Delgado, E. Santos, F. Mendes, J. Duarte, M. Baía, \& M. Figueiredo (Eds.), Tarefas matemáticas: Livro de Atas do Encontro de Investigação em Educação Matemática (EIEM2014) (pp. 81-93). Lisbon, Portugal: SPIEM.

Guerreiro, H. G., \& Serrazina, L. (2015). A construção do conceito de número racional através de múltiplas representações [The construction of the concept of rational number through multiple representations]. In L. Santos, M. V. Pires, R. T. Ferreira, A. Domingos, C. Martins, H. Martinho, I. Vale, N. Amado, S. Carreira, \& T. Pimentel (Eds.), Investigação em educação matemática: Representações matemáticas (pp. 99-113). Lisbon, Portugal: SPIEM. 
Keijzer, R. (2003). Teaching formal mathematics in primary education: Fraction learning as a mathematising process. Utrecht, the Netherlands: CD- $\beta$ Press/Freudenthal Institute, Utrecht University.

Kraemer, J., \& Paardekooper, E. (1998). Développement des connaissance et compétences des élèves et des professeurs dans un contexte de soutien des apprentissages [Development of knowledge and competences of teachers in a context of supporting learning]. In P. Abrantes, J. Porfírio, \& M. Baía (Eds.), The interactions in the mathematics classroom. Proceedings of the CIEAEM 49 (pp. 63-75). Setubal, Portugal: Escola superior de Educacao de Setubal.

Kraemer, J. M., \& van Benthem, M. (2011). Diagnosticeren en plannen in de bovenbouw [Diagnosing and planing in teaching]. Arnhem, the Netherlands: Cito.

Mata-Pereira, J., \& Ponte, J. P. (2013). Desenvolvendo o raciocínio matemático: Generalização e justificação no estudo das inequações [Developing mathematical reasoning: Generalisation and justification in the study of inequalities]. Boletim GEPEM, 62, 17-31.

Matos, J. M. L. (1984). Van Hiele levels of preservice primary teachers in Portugal. Master's dissertation University of Boston.

Mendes, F. (2012). A aprendizagem da multiplicação numa perspetiva de desenvolvimento do sentido de número: Um estudo com alunos do $1 .^{\circ}$ ciclo [Learning multiplication in a perspective of developing number sense: A study with grade 1 students] (Doctoral thesis). Lisbon, Portugal: University of Lisbon.

Mestre, C., \& Oliveira, H. (2013). Um percurso na generalização matemática: Uma experiência de ensino no $4 .^{\circ}$ ano [A journey in mathematical generalisation: A teaching experiment at grade 4]. In L. Santos, A. Domingos, I. Vale, M. J. Saraiva, M. Rodrigues, M. C. Costa, \& R. A. T. Ferreira (Eds.), Investigação em Educação Matemática 2013: Raciocínio Matemático (pp. 254-276). Lisbon, Portugal: SPIEM.

Mestrinho, N., \& Oliveira, H. (2012). A integração do tangram na aula de geometria: Uma primeira abordagem ao conceito de área na formação inicial de professores dos primeiros anos [The integration of the tangram in the geometry classroom: A first study of the concept of area in elementary school teachers' initial education]. In A. P. Canavarro, L. Santos, A. M. Boavida, H. Oliveira, L. Menezes, \& S. Carreira (Eds.), Práticas de ensino da Matemática: Atas do Encontro de Investigação em Educação Matemática (pp. 529-540). Lisbon, Portugal: SPIEM.

Ministério da Educação (ME). (2007). Programa de matemática do ensino básico (Mathematics curriculum of basic education). Lisbon, Portugal: DGIDC.

Monteiro, C., \& Pinto, H. (2006). A aprendizagem dos números racionais [Learning rational numbers]. Quadrante, 14(1), 89-108.

Pereira, M., \& Saraiva, M. J. (2013). Um modelo de ensino-aprendizagem de parâmetros em funções: Um estudo com alunos do ensino secundário [A model of teaching and learning parameters in functions: A study with secondary school students]. In L. Santos, A. Domingos, I. Vale, M. J. Saraiva, M. Rodrigues, M. C. Costa, \& R. A. T. Ferreira (Eds.), Investigação em Educação Matemática 2013: Raciocínio Matemático (pp. 297-317). Lisbon, Portugal: SPIEM.

Pimenta, C., \& Saraiva, M. J. (2013). O desenvolvimento do pensamento algébrico nos primeiros anos do ensino básico [The development of algebraic thinking at the first years of basic education]. In L. Santos, A. Domingos, I. Vale, M. J. Saraiva, M. Rodrigues, M. C. Costa, \& R. A. T. Ferreira (Eds.), Investigação em Educação Matemática 2013: Raciocínio Matemático (pp. 318-341). Lisbon, Portugal: SPIEM.

Pinheiro, A., \& Carreira, S. (2013). O desenvolvimento do raciocínio geométrico no tópico triângulos e quadriláteros [The development of geometrical reasoning in the topic of triangles and quadrilaterals]. In L. Santos, A. Domingos, I. Vale, M. J. Saraiva, M. Rodrigues, M. C. Costa, \& R. A. T. Ferreira (Eds.), Investigação em Educação Matemática 2013: Raciocínio Matemático (pp. 146-169). Lisbon, Portugal: SPIEM.

Pinto, H. (2011). O desenvolvimento do sentido da multiplicação e da divisão de números racionais [The development of multiplication and division sense of rational numbers] (Doctoral thesis). Lisbon, Portugal: University of Lisbon. 
Ponte, J. P. (2005). Álgebra no currículo escolar [Algebra in the school curriculum]. Educação $e$ Matemática, 85, 36-42.

Ponte, J. P., \& Quaresma, M. (2011). Abordagem exploratória com representações múltiplas na aprendizagem dos números racionais: Um estudo de desenvolvimento curricular [Exploratory approach with multiple representations in learning rational numbers: A curriculum development study]. Quadrante, 20(1), 53-81.

Ponte, J. P., \& Quaresma, M. (2014a). Representações e processos de raciocínio na comparação e ordenação de números racionais numa abordagem exploratória [Representations and reasoning processes in comparting and ordering rational numbers in an exploratory approach]. BOLEMA, 28(50), 1464-1484.

Ponte, J. P., \& Quaresma, M. (2014b). Representações e raciocínio matemático dos alunos na resolução de tarefas envolvendo números racionais numa abordagem exploratória [Representations and mathematical reasoning in solving tasks involving rational numbers in an exploratory approach]. Uni-Pluri/Versidad, 14(2), 102-114.

Ponte, J. P., Branco, N., \& Matos, A. (2008). O simbolismo e o desenvolvimento do pensamento algébrico dos alunos [Simbolism and development of students' algebraic thinking]. Educação $e$ Matemática, 100, 89-95.

Ponte, J. P., Mata-Pereira, J., \& Henriques, A. (2012). O raciocínio matemático nos alunos do ensino básico e do ensino superior [Mathematical reasoning in basic and higher education students]. Praxis Educativa, 7(2), 355-377.

Quaresma, M., \& Ponte, J. P. (2012). Compreensão dos números racionais, comparação e ordenação: O caso de Leonor [Understanding rational numbers, comparing and ordering]. Interacções, 20, 37-69.

Rocha, I., \& Menino, H. (2009). Desenvolvimento do sentido do número na multiplicação. Um estudo de caso com crianças de 7/8 anos [Development of number sense in multiplication: A case study with 7/8 years old children]. Relime, 12(1), 103-134.

Rodrigues, M. (2010). El sentido del número: Una experiencia de aprendizaje y desarrollo en educación infantile [Number sense: A learning and development experience in infant education] (Doctoral thesis). Universidad de Extremadura, Spain.

Silvestre, A. I., \& Ponte, J. P. (2012). Proporcionalidade directa no 6. ${ }^{\circ}$ ano de escolaridade: Uma abordagem exploratória [Direct proportion at grade 6: An exploratory approach]. Interacções, 20, 137-158.

Streefland, L. (1986). Rational analysis of realistic mathematics education as a theoretical source for psychology: Fractions as a paradigm. European Journal of Psychology of Education, 1(2), 67-82.

Streefland, L. (1991). Fractions an integrated perspective. In L. Streefland (Ed.), Realistic mathematics education in primary school (pp. 93-118). Utrecht, the Netherlands: CD- $ß$ Press/Freudenthal Institute, Utrecht University.

Streefland, L. (1993). Fractions: A realistic approach. In T. Carpenter, E. Fennema, \& T. Romberg (Eds.), Rational numbers, an integration for research (pp. 289-327). Mahwah, NJ: Laurence Erlbaum.

Streefland, L. (2003). Learning from history for teaching in the future. Educational Studies in Mathematics, 54, 37-62.

Treffers, A. (1987). Three dimensions. A model of goal and theory description in mathematics instruction-The Wiskobas project. Dordrecht, the Netherlands: D. Reidel.

Treffers, A. (1991). Didactical background of a mathematics program for primary education. In L. Streefland (Ed.), Realistic mathematics education in primary school (pp. 21-56). Utrecht, the Netherlands: CD- $\beta$ Press/Freudenthal Institute, Utrecht University.

Treffers, A., \& Buys, K. (2008). Grade 2 (and 3) -Calculation up to 100. In M. van den HeuvelPanhuizen (Ed.), Children learn mathematics. A learning-teaching trajectory with intermediate attainment targets for calculation with whole numbers in primary school (pp. 61-88). Rotterdam, the Netherlands: Sense. 
Treffers, A., \& Goffree, F. (1985). Rational analysis of realistic mathematics education: The Wiskobas program. In L. Streefland (Ed.), Proceedings of the Ninth International Conference for the Psychology of Mathematics Education (pp. 97-122). Utrecht, the Netherlands: OW\&OC, Utrecht University.

Van den Heuvel-Panhuizen, M. (1996). Assessment and realistic mathematics education. Utrecht, the Netherlands: CD- $\beta$ Press/Freudenthal Institute, Utrecht University.

Van den Heuvel-Panhuizen, M. (1998). Realistic mathematics education: Work in progress. In T. Breiteig \& G. Brekke (Eds.), Theory into practice in mathematics education. Proceedings of Norma98, Second Nordic Conference on Mathematics Education. Kristiansand, Norway: Agder College, Research Series No. 13.

Van den Heuvel-Panhuizen, M. (2003). The didactical use of models in realistic mathematics education: An example from a longitudinal trajectory on percentage. Educational Studies in Mathematics, 54(1), 9-35.

Van den Heuvel-Panhuizen, M. (Ed.) (2008). Children learn mathematics: A learning-teaching trajectory with intermediate attainment targets for calculation with whole numbers in primary school. Rotterdam, the Netherlands: Sense.

Van den Heuvel-Panhuizen, M., \& Wijers, M. M. (2005). Mathematics standards and curricula in the Netherlands. Zentrallblatt fur Didaktik der Mathematik, 37(4), 287-307.

Van Hiele, P. M. (1984). A child's thought and geometry. In D. Fuys, D. Geddes, \& R. Tischler (Eds.), English translation of selected writings of Dina van Hiele-Geldof and Pierre M. van Hiele (pp. 243-252). New York, NY: Brooklyn College School of Education.

Ventura, H. (2014). A aprendizagem dos números racionais através das conexões entre as suas representações: Uma experiência de ensino no $2 .^{\circ}$ ciclo do ensino básico [Learning rational numbers through the connections among their representations: An experience at 2 nd cycle of basic education] (Doctoral thesis). Lisbon, Portugal: University of Lisbon.

Webb, D., Boswinkel, N., \& Dekker, T. (2008). Beneath the tip of the iceberg: Using representations to support pupil understanding. Mathematics Teaching in the Middle School, 14(2), 110-113.

Open Access This chapter is distributed under the terms of the Creative Commons Attribution 4.0 International License (http://creativecommons.org/licenses/by/4.0/), which permits use, duplication, adaptation, distribution and reproduction in any medium or format, as long as you give appropriate credit to the original author(s) and the source, a link is provided to the Creative Commons license and any changes made are indicated.

The images or other third party material in this chapter are included in the work's Creative Commons license, unless indicated otherwise in the credit line; if such material is not included in the work's Creative Commons license and the respective action is not permitted by statutory regulation, users will need to obtain permission from the license holder to duplicate, adapt or reproduce the material.

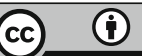

